life on land at an early date. Being female, ferocious and an advocate of an unpopular view, she didn't get many grants. But as biologist William Shear wrote in her obituary, she "was as astute at playing the stock market as she was at interpreting fossil spores, and used her independent wealth to fund her own research" (see Nature 405, $34 ; 2000)$.

Gregory Retallack of the University of Oregon in Eugene, like Jane Gray, is unafraid to plough a contrarian furrow in this muchdebated area. For many years now, he has worked on palaeosols from the Precambrian. The problem with fossil soils is that they are conventionally recognized by traces of the organisms that lived in them, especially plant roots. There lies a conundrum - how do you recognize a palaeosol in sediment that lacks plant roots? The answer comes through careful geological work, to show that the palaeosol is associated with rock formed under non-marine conditions, together with work on geochemistry and data from stable isotopes. But there might also be direct evidence in the fossil soil, in the form of carbonate nodules, sand crystals and cracks caused by desiccation or the presence of ice.

Evidence of this sort has now led Retallack to infer the presence of palaeosols among rocks from the Ediacaran period (635 million to 542 million years ago) of South Australia. One might think that soils from the latest Precambrian are hardly controversial, even by the standards of a highly charged field. But these rocks contain fairly abundant evidence for the first macroscopic life - which, until now, was widely assumed to have been marine.

Ediacaran rocks feature a wide range of large, distinctive and yet enigmatic structures, usually thought to be fossils of living creatures. Originally found in South Australia, Ediacaran fossils have since been discovered in localities as far-flung as Newfoundland in Canada, Arctic Russia and the English Midlands.

The Ediacarans, however, were a rum lot. Although clearly highly organized, their precise nature has been elusive. If they were animals, they bore little or no resemblance to any other creatures, either fossil or extant. This has led to suggestions that they were giant protists, fungi,

algae, lichens or even a kind of life entirely different from anything else known and now wholly extinct.

Perhaps the only point of agreement is that, whatever else they were, the Ediacarans lived on the sandy beds of shallow, sunlit seas. This is where Retallack parts company with just about everyone else, because some of his Ediacaran palaeosols are associated with Ediacaran fossils. This would mean that at least some Ediacarans lived on land,

"The stately progression of life from water to land was not necessarily a single, simple narrative." under the sky, perhaps in the manner of lichens, or microbial colonies that form soil crusts. The Ediacarans, then, would be the now-not-so-rare (and not at all mythical) creatures that first colonized the land - not just in puddles, but in soils indicative of a dry, cold desert. This is as far away as imaginable from the oceanic idyll that many have assumed for Ediacaran organisms, and have reconstructed as such in a million coffee-table books.

These conclusions are published in a paper on Nature's website this week (G. J. Retallack Nature http://dx.doi.org/10.1038/nature11777; 2012) and will cause sharp intakes of breath in the palaeontological community; so much so that we have commissioned a News and Views Forum to air the arguments (S. Xiao \& L. P. Knauth Nature http:// dx.doi.org/10.1038/nature 11765; 2012).

More work - and more science - will be the only way to validate this challenging and exciting work. But the lesson from the past is clear. Jane Gray's advocacy of land life in the relatively recent Ordovician period (485 million to 443 million years ago), once seen as off-the-wall, is now orthodoxy. There is nothing outré in principle in the supposition that life of some sort, however humble, lived on land from a very early date: the stately progression of life from water to land was not necessarily the single, simple narrative that seems so cut and dried in retrospect. The fossil record has this irritating habit: just when everyone thinks that the narrative has been sorted out, something comes along to force the story in a new, unexpected and breathtaking direction.
ANNOUNCEMENT

\section{A new iPad app for Nature readers}

$\mathrm{M}$ any publishers hope that tablet renditions of newspapers and magazines will revive the fortunes of once-mighty but now financially stressed publications founded in print. Nature's fortunes over the years have been relatively positive. Its print circulation has declined since its peak in 2002, but not as markedly as those of many other publications. Meanwhile, the online readership of Nature is more than 3 million unique users every month, and growing significantly year on year.

However, there is a world of difference in user experience between Nature on a desktop computer or laptop and a digital rendition that captures the feel and easy portability of the weekly print issue with the added features that an online platform allows. Although Nature has had an iPad version since January 2011, a version is now being released that includes the weekly edition in its traditionally structured form. Existing personal subscribers to Nature have full access to the tablet edition. New subscribers can choose to buy only the iPad version at a comparatively low price (see go.nature.com/pvfvqy).

Nine journals from the Nature Publishing Group are included in this app: Nature, Nature Biotechnology, Nature Medicine, Nature
Physics, Nature Genetics, Nature Reviews Genetics, Nature Reviews Microbiology, Nature Communications and Scientific Reports. Also included are News articles and papers published online but not yet available in print. More journals will follow next year.

At present, the accessibility of these diverse strands of content varies. Access for much of it is unrestricted. All of Nature's journalistic output is freely available. Scientific Reports is a 'gold' openaccess journal - in other words, its papers are freely available, in their final published form, to anybody from the moment of publication. Nature Communications has about half of its content openly accessible. All of the rest is from now on available in the new iPad app, although so far only to personal print and iPad subscribers. We aim to provide access arrangements for readers who work at institutions with an online-only site licence by the middle of 2013.

The journals iPad app has been designed to deliver a reading experience that has all the clarity and convenience of print while surpassing print in its various functions. Alongside the issue-based navigation and tables of content, the new version allows the following: sharing; accessible bookmarks; saved searches (synced with nature.com); downloading of PDF files of articles; variable font sizes; figures at a glance in a figure-viewing panel; downloading and offline access to the journals; active links for references; and enhanced navigation from within the article.

We hope that those who value Nature will find its tablet edition even more stimulating and useful than the more traditional renditions. 